\title{
Results from a systematic writing program in grief process: part 2
}

\author{
This article was published in the following Dove Press journal: \\ Patient Preference and Adherence \\ 5 January 20 I I \\ Number of times this article has been viewed
}

\section{Bodil Furnes \\ Elin Dysvik}

University of Stavanger, Faculty of Social Sciences, Department of Health Studies, N-4036 Stavanger, Norway
Correspondence: Bodil Furnes University of Stavanger, Faculty of Social Sciences, Department of Health Studies, N-4036 Stavanger, Norway

Tel +475I834I 000

Fax +4751831550

Email bodil.furnes@uis.no
Objective: This paper, the second of two, reports the results of a systematic writing program used as a tool in the grief process. The study was based on a specifically developed program, which has been described and discussed previously in Part 1.

Methods: The study had a qualitative research design, with a hermeneutic phenomenological approach. The research tool of the study, a writing program, was developed and implemented. A purposive sample was used, consisting of 13 bereaved adults.

Results: From an analysis of all of the texts written during the program, we drew four conclusions. Writing yields new thoughts and increases knowledge. Writing is stressful as well as a relief. Writing awakens and preserves memories. The value of writing is related to the forms, ways, and situations of writing.

Conclusion: We have discussed handling grief with a unique process. Our findings reveal a great breadth and variation in the experiences associated with different writing forms, ways of writing, and writing situations. This implies that flexibility and individualization are important when implementing grief management programs like this. We believe that a structured writing program can be helpful in promoting thought activity and as a tool to gain increased coherence and understanding of the grief process. This writing program may be a valuable guide for program development and future research.

Keywords: bereavement, grief, writing

\section{Introduction}

Past and more recent research has documented a relationship between loss, grief, and suffering and the development of ill health. Studies of writing and its effect on health indicate a potential positive health gain through writing about traumatic and challenging experiences. ${ }^{1-4}$ These studies and writing theory emphasize several benefits of writing, including the release of feelings, in allowing reflection and clarification, increased awareness, and new insights. ${ }^{5-10}$

\section{Theoretical framework Grief}

The traditional understanding of grief emphasizes that grief is a predictable series of reactions, occurring in specific stages that are inevitable and lead to recovery. For most of the 20th century, the dominant view was that grief is of limited duration and follows set stages, and that the aim of grief work is to free the bereaved of ties to the loved one. ${ }^{11-14}$ Several researchers involved in more recent grief theory are critical of the traditional belief that the reactions following loss are necessary and predictable. 
These researchers also question the focus on the disruption of ties. ${ }^{15-20}$ They argue that dealing with grief varies among bereaved persons, and that the grief process has no defined limits to its stages or duration. According to this more recent understanding of grief, dealing with grief is an experience that is ongoing, a movement between adaptation and relearning the world. ${ }^{21}$ The grief process changes in nature over time, but it involves a continuing relationship with the deceased that allows both an "appropriate" experience of grief and continuing involvement with the living. ${ }^{18,22,23}$ According to the phenomenological perspective on grief, assistance should be directed towards the bereaved individual's expressed experience of his/her bereavement. ${ }^{21,24}$ Therefore, grief is a life phenomenon, which means that each person experiences, interprets, and understands his/her grief in a unique way. These experiences vary in their forms and complexity. The notion that grief is a life phenomenon means that grief touches everything experienced in the life situation, and involves moving into a changed world with new experiences and ways of encountering the world. ${ }^{9,21,24}$ Both the classical and recent understandings of grief stress that grief work is an active process. ${ }^{9} 16,18,19,21,22,24$ In giving support and assistance to a bereaved person, we must take into account that grief is a unique experience, an active movement, and an inevitable part of life.

\section{Language and thought}

We interpret and understand through language. The connection between language and the attainment of knowledge is clear in both phenomenology and process-oriented writing theory. According to phenomenological understanding, emotions are embedded in the body as impressions and we experience them as impressions..$^{24,25}$ The experience of grief creates an impression, and when this impression finds its articulation, the person may achieve understanding. ${ }^{24}$

The philosopher Ricoeur ${ }^{26-28}$ emphasizes that narration is reflection on events. In a story, a pattern of understanding is formed based on one's experiences. According to Ricoeur, this narration yields new insights and new stories.

In process-oriented writing theory, it is fundamental that writing is a creative process, in which language is related to thought. Thoughts emerge during writing and the writer may experience increased awareness and knowledge. .,6,8,29-31 $^{-1}$ According to this theory, it is claimed that an active use of language stimulates and promotes thought activity and learning, and that putting ideas, images, and feelings into words allows us to clarify, understand, and structure them. Moreover, writing may help to identify new relations and reveal any lack of coherence and understanding. Qualities such as increased awareness, organization, new insights, and acknowledgment are certainly factors that are essential in dealing with grief. ${ }^{18,19,21,22}$ Therefore, writing during the grief process may be valuable.

\section{Group approach}

Group programs are common in settings associated with therapy in health care. ${ }^{32}$ Participation in groups may also increase the power of writing. ${ }^{24}$ At the same time, the communality experienced may encourage greater attention to outside life circumstances among bereaved people. Group approaches have many advantages in the treatment of grief and loss caused by death, and the group provides a setting in which bereaved individuals can be in touch with others with similar problems. Group participation can help these individuals gain a better understanding of the grief situation, and the roles of their behavior, thoughts, and feelings in their perception of their situation. ${ }^{33}$

\section{Aim}

Based on previous considerations, the overall aim of this study was to examine the experiences and results of a systematic writing program in order to evaluate the value and appropriateness of writing in the grief process.

\section{Methods}

The study had a qualitative research design, with a hermeneutic phenomenological approach. The study's research tool was a specifically constructed and implemented writing program.

A purposive sample was used, consisting of 13 bereaved adults (10 women and three men), who had lost either a spouse, cohabitant, sibling, or parent. They were divided into two groups (Table 1). Thus, the researchers' knowledge of the population and its elements was used to handpick typical cases to be included in the sample.

The bases for group participation were similar experiences of loss by death and ages, to ensure beneficial group processes and affiliations.

Table I Participants and background information $(\mathrm{N}=10$ women and 3 men)

\begin{tabular}{ll}
\hline Age & $20-59$ years \\
Time since loss & 4 months -1.5 years \\
Type of loss & Expected/unexpected death \\
Group assignment & I. spouse or cohabitant \\
& 2. parent or sibling \\
\hline
\end{tabular}




\section{Inclusion criteria}

- Bereaved adult women and men

- Aged 20-70 years

- Loss of a close person by death

- Self-reported need for help

\section{Exclusion criteria}

- Bereaved individual had experienced the loss of a child

- Lack of motivation to participate

- Unwilling to attend a group

- Major psychological problems

\section{The writing program}

The study's research tool was a specifically constructed and implemented writing program, based on the theoretical framework highlighted in Part $1^{10}$ and the findings of two review articles. ${ }^{3,7}$ The participants in the writing program were divided into two groups: one group consisted of individuals who had experienced the loss of a spouse or partner, and the other group consisted of individuals who had lost a parent or sibling. Those leading the groups were deacons with group grief work experience and knowledge of process-oriented writing.

Throughout the writing program, writing followed two parallel tracks: writing in the grief writing group and writing at home in a diary. The writing program lasted for 5 months, during which group meetings were held every
2 weeks during the initial 3 months, and 1 meeting was held in each of the last 2 months, for a total of 10 meetings.

The forms of writing that were incorporated into the writing program were free writing and focused writing. ${ }^{10}$ The organization and content of the writing program are described in Table 2.

\section{Empirical data}

The empirical data are the "report texts" written by the bereaved and submitted anonymously. These texts (the process reports) were written after the writing periods in the grief writing groups and after the periods of diary writing at home. Each individual participant also composed a more extensive report text (the final report) 2 weeks after the completion of the writing program.

\section{Analysis and interpretation}

Analysis and interpretation were inspired by the thinking of Ricoeur. ${ }^{24,34}$ The perception of language as discourse emphasizes the relationship of language to practice, as utterance and as realization in a specific situation. The text is autonomous. It is the bearer of a message and allows room for interpretation. As such, the text's speech and the writer's reference in the text allow the reader to understand it. Reading the text is a dialectic between two attitudes: explanation and understanding. According to Ricoeur, both these potentialities

Table 2 Organization, writing situations, and topics of the writing program

\begin{tabular}{|c|c|c|}
\hline Organization & $\begin{array}{l}10 \text { meetings over } 5 \text { months (in total): } \\
\text { - Every second week for } 3 \text { months, for } 2.5 \mathrm{~h} \\
\text { - Once a month thereafter, for } 2.5 \mathrm{~h}\end{array}$ & \\
\hline \multicolumn{3}{|c|}{ Writing situations and topics } \\
\hline Meeting & Group writing & Home writing \\
\hline I & Writing about the present life situation & Writing diary \\
\hline 2 & A description of the person who is lost & Writing diary \\
\hline 3 & $\begin{array}{l}\text { A story about an important occasion spent } \\
\text { with the person who is lost }\end{array}$ & Writing diary \\
\hline 4 & Writing a letter/obituary for the lost person & Writing diary \\
\hline 5 & Defining “despair” and "guilt” & Writing diary \\
\hline 6 & $\begin{array}{l}\text { Writing a story based on pictures that } \\
\text { illustrate different aspects of grief } \\
\text { experience }\end{array}$ & Home writing based on a previous theme; writing diary \\
\hline 7 & Defining loss and loneliness & Home writing about a good memory; writing diary \\
\hline 8 & $\begin{array}{l}\text { Previous and present relationship to } \\
\text { important persons }\end{array}$ & $\begin{array}{l}\text { Home writing about good and bad thoughts and feelings } \\
\text { experienced during the last few days; writing diary }\end{array}$ \\
\hline 9 & Experience of grief, longing, hope, and joy & $\begin{array}{l}\text { Home writing about situations related to a strong feeling } \\
\text { of grief/situations related to joy; writing diary }\end{array}$ \\
\hline 10 & $\begin{array}{l}\text { Writing about the things that are important } \\
\text { to know; the capacity to meet the new life } \\
\text { situation; a meaningful life; and future plans }\end{array}$ & \\
\hline
\end{tabular}


belong to the reading of a text. The analysis and interpretative work of this study were based on this type of approach.

Analysis and interpretation followed 4 stages:

1. Naïve reading of all report texts, arriving at an overall view.

2. Structural analysis: i) text and structure; ii) content and structure.

3. Interpretation of the explanatory structures and understanding the content form of the thematization in 4 main themes.

4. Critical interpretation and discussion.

\section{Results}

The data that were analyzed represent thick descriptions (Table 3). From the analysis of all the report texts, certain conclusions were drawn: writing yields new thoughts and increases knowledge; writing is a strain as well as a relief; writing awakens and preserves memories; the value of writing is related to the forms, ways, and situations of the writing. To give an overview of our findings, some data from the text reports are presented.

\section{Writing yields new thoughts and increases knowledge}

Several text reports emphasized the relationship between writing and thinking, and pointed to the creative elements in writing and thought processes. The majority of these text reports stated that writing reveals the writer's thoughts and feelings. Writing also stimulates thinking, and new thoughts occur, together with new questions and insights. One report emphasized this in this way:

Sometimes I am surprised, I do not always have much to say when I sit down to write. But it is unbelievable how much appears after a while and insists on being written down. When I sit with my pen, I often wish I had 10 pens at the same time so I could write it all down. The scope of my thoughts is extended so that I would like to get it all down on the paper simultaneously!

\section{Writing is a strain as well as a relief}

Several report texts stated that writing was a painful experience. It was painful to have to remember and to reflect upon these memories, and to manage difficult thoughts and feelings. However, expressions of relief at the release achieved were also documented:

Especially in the beginning, when I struggled so much with sadness that I almost could not function in daily life, it was easy to resort to the diary, a kind of safety valve to get rid of the thoughts and feelings that tumbled out.

The ambiguity of the experiences encountered when writing was used as a tool for dealing with grief was also clearly described. These different expressions are illustrated below:

Painful thoughts and feelings appeared. Although it is difficult to write, it feels like a kind of purification. It feels good to have finished this.

Table 3 Example of the clarification of stages 2 and 3 of the analysis process

\begin{tabular}{|c|c|c|}
\hline $\begin{array}{l}\text { Meaning unit } \\
\text { What is said }\end{array}$ & $\begin{array}{l}\text { Significance } \\
\text { What it is about }\end{array}$ & $\begin{array}{l}\text { Theme } \\
\text { Writing yields new thoughts } \\
\text { and increases knowledge }\end{array}$ \\
\hline "the spectrum of my mind expands" & The creative elements of writing & Writing leads to new thoughts \\
\hline "the thoughts came as I wrote" & New questions arise as a result of writing & Writing promotes thinking \\
\hline \multicolumn{3}{|l|}{ "many more thoughts appear than usually" } \\
\hline \multicolumn{3}{|l|}{ "the words came floating" } \\
\hline \multicolumn{3}{|l|}{ "the writing ended up with lots of questions" } \\
\hline "I became more aware of what I struggle with" & Clarification related to writing & Writing expands insight \\
\hline "analyzing, self-analysis of the thoughts" & Awareness of writing & \\
\hline \multicolumn{3}{|l|}{ "being aware of my thoughts" } \\
\hline \multicolumn{3}{|l|}{ "sometimes explanations of why come up" } \\
\hline \multicolumn{3}{|l|}{ "the writing gave me an 'aha' experience" } \\
\hline "progress in the process" & Expanded perspective & Writing as understanding \\
\hline "I advanced in the process" & Clarification related to writing & Writing as discovery and insight \\
\hline "the writing is a tool to make progress" & Awareness of writing & \\
\hline \multicolumn{3}{|l|}{ "discover what is important to me" } \\
\hline \multicolumn{3}{|l|}{ "makes me aware of other aspects" } \\
\hline And so on ... & And so on ... & And so on ... \\
\hline
\end{tabular}


It was painful and agonizing to write down thoughts and feelings, although the writing was therapeutic and revealing.

\section{Writing awakens and preserves memories}

Several report texts seemed to express that writing memories clarified that the loss was real. The importance of preserving good memories was also emphasized:

Suddenly it became clear how many good memories I had from that time. It felt good to remember these old memories ... it made me look backwards to see NN ... this was rather tough, the memories flowed, but this was a very good topic to write about.

I have to remind myself that this is reality and that I have to preserve the narratives in my heart ... what I have written must not disappear as it is something I might pick up later.

\section{The value of writing is related to the forms, ways, and situations of writing}

The value of writing differs with the forms and topics used in the writing process. As illustrated above, an expressive form of writing can represent feelings and personal experiences. In several text reports, this was emphasized as having a positive value in grief work, even though it could also be a strain. However, a focused form of writing seems to allow a distance to be maintained from one's feelings and experiences. This was reported in positive ways:

The task gave me an opportunity to stick to the described themes and to choose how much personal experiences I wished to include.

This writing form is also described as "sparing". Contrary to a fragmented style of writing or one based on a keyword, the narrative way of writing was related to more valuable aspects, such as "awareness", "clarification", "organization", and "memory preservation". Surprisingly, several reports stated that writing in the group situation was easier than writing at home:

It seems easier to concentrate when writing in groups compared with writing at home. Sometimes it is such a heavy burden to practice home writing and I chose to avoid it. It was easier for me to write in the group community where I felt closeness and contact.
I admit that it was easier to write and then talk about it in the group. I had the opportunity to express my thoughts on paper and then to express my thoughts verbally in the group and receive immediate feedback.

However, a few participants stressed that writing at home was very valuable:

The diary acts as a safety valve, a tool to get through particularly difficult and painful moments.

\section{Critical interpretation and discussion}

In this section, the thematized results from the previous section are linked and will be discussed in relation to the theoretical framework. Based on previous considerations, the overall aim was to highlight the experiences and results of a systematic writing program to evaluate the value and appropriateness of writing during the grief process.

According to Lipps, ${ }^{25}$ we are moved bodily when we experience. In this movement, experiences that are formed as impressions will find utterance. Our data indicate that the writing process may have a liberating effect on the impression. Articulation seems to put pressure on the impression, and one could say that writing the grief experience in the group sessions and in the diary "opens up". Several bereaved individuals in this study described this movement as "release" and a feeling of liberation. The use of a metaphor like "safety valve" could reflect the relief function of writing, when the pressure becomes too high. This is also described as a painful process, as the writing can be agonizing. Even so, it is still described as a relief. We presume that the body is relieved through the utterance of the impression during the writing process. ${ }^{24}$ However, this is also related to a feeling of strain. This can be understood in that the articulation may also create a confrontation with complex experiences. This process also makes room for new thoughts and facets of the grief experience. This is similar to the reports of Elbow, ${ }^{5,6}$ who stressed that the writing process both creates thoughts and eases thoughts. As demonstrated in our study, new thoughts and insights can be gained as the impression is clarified.

Our results clearly show that increased understanding, insight, and meaning were developed through the writing process. For the bereaved individuals in this study, writing became a sort of tool to handle the grief process by letting their grief be expressed. Simultaneously, this writing may be revealing and clarifying. Several language and writing 
researchers emphasize that free writing is an introspective technique of discovery. This expressive, exploratory writing is personal; it is closest to inner speech and the thought process itself., 5 This form of writing, as revealed through the analysis of our empirical data, has the effect of raising the participant's awareness. This may also explain the therapeutic effects of free writing.

The assignments, which encouraged focused writing, were more clearly limited when the writer had to respond to something specific. An informative kind of writing may result when a more defined form of writing is required. ${ }^{30}$ In this study, focused writing was clearly described as less painful and more sparing than free writing. We believe that this form of writing allows a distance to be established between the writer and his/her painful thoughts and feelings. Such focused writing might also lead and stimulate to more personal writing. On this basis, we also note the possible therapeutic value of focused writing in grief work.

Clarification and new perspectives are part of the grief process, illustrated as a movement between "adaptation and relearning the world" in our model. ${ }^{21}$ Here, this understanding is manifested when the bereaved describes changed ways of understanding and his/her interpretation of self-understanding. In this kind of work, the empirical data revealed that language and narration are important in gaining new experiences and new ways of encountering the world. This is supported by several other authors. ${ }^{26-28,35-37}$ Grief work implies a painful struggle to regain continuity in life and to restore an experience of wholeness. ${ }^{21,24}$ Our results regarding the benefits of writing and narration are similar to the views of Ricour and Neimeyer, who emphasize that we reflect on events through narration. ${ }^{26-28,35,36}$ The creative process is central when writing and telling. The participants' earlier experiences may be seen in a new light, and nuances appear. Put another way, writing in its own right can promote thought activity, and increased awareness, organization, and acknowledgment are important in dealing with grief. ${ }^{16,18-20,22,38}$

Recent grief theory underlines the positive value of the ties to the person who is lost as a source of further enrichment of life. ${ }^{18,22}$ Through writing and narration, the bereaved individuals experienced the awakening and preservation of memories. Several researchers ${ }^{15,18,24}$ have noted that bringing up memories can result in shaping self-understanding, creating meaning, and establishing good feelings. Memories associated with important events experienced with the person who is lost create a connection, so that loss and grief can contribute to something valuable. Memory writing may be a way of continuing the relationship. This is considered essential in grief work, ${ }^{18,24}$ and can also contribute comfort and support in the altered life situation of the bereaved individual. However, although memory writing may also evoke sadness and revivify painful experiences, writing that concentrates on good memories can be a way to cultivate and deal with some of these painful thoughts and feelings in this group of individuals. ${ }^{24}$

Our empirical data indicate that writing associated with conversations in the grief writing groups was especially valuable in the grief work. A feeling of community with the other participants and the possibility of sharing their thoughts and feelings after having written them were noted. According to MacKenzie, ${ }^{32}$ a group has important therapeutic properties of its own, and several important therapeutic factors have been identified, including community, listeners, and conversation partners. These factors also seemed to be important in our study, and closeness, contact, and feedback were especially emphasized in the empirical data. Our findings are also supported by Keefe et al, ${ }^{33}$ who stated that group participation can help patients gain a better understanding of the grief situation, and the roles of their own behavior, thoughts, and feelings. Writing a diary at home can also be a valuable contribution to the grief process. However, it appears that writing at home with no group talks or other follow-up was experienced as an additional strain. Contrary to our expectations, writing in groups was considered to be more valuable than writing at home.

From a phenomenological perspective, the grief experience involves moving into a changed life situation, with new experiences and ways of encountering the world. ${ }^{9,21,24}$ Here, writing as the articulation of impressions and as narration may give the grieving person an opportunity to gain new understanding and grasp the unique experience of the grief situation, as indicated in our writing program.

\section{Conclusion}

Our findings show a great breadth and variation in the experiences associated with grief and writing. This implies that flexibility and individualization are important when implementing grief management programs like this one. Based on our suggested platform for understanding grief work, described in Part $1^{10}$ of this two-part article, and the present findings, writing may be performed within a systematic writing program. This writing may also be an integral part of traditional grief groups or discussion groups. We believe that writing might be helpful in promoting thought activity and as a tool for 
gaining increased coherence and understanding in the grief process. In clinical practice, writing can be an alternative and/ or supplement to the care and follow-up of the bereaved. The writing program implemented and discussed here may be valuable in guiding program development and future research.

\section{Disclosure}

The authors disclose no conflicts of interest.

\section{References}

1. Francis ME, Pennebaker JW. Putting stress into words: The impact of writing on physiological, absentee and self-reported emotional wellbeing measures. Am J Health Promot. 1992;6:280-207.

2. Smyth J. Written emotional expression: Effect sizes, outcome types, and moderating variables. J Consult Clin Psychol. 1998;66:174-184.

3. Baikie KA, Wilhelm K. Emotional and physical health benefits of expressive writing. Advances in Psychiatric Treatment. 2005;11: 338-346.

4. Pennebaker JW. Writing, social processes and psychotherapy: From past to future. In: Lepore SJ, Smyth JM, editors. The Writing Cure: How Expressive Writing Promotes Health and Emotional Well-Being. Washington DC: American Psychological Association; 2002:281-291.

5. Elbow P. Writing Without Teachers. New York: Oxford University Press; 1973.

6. Elbow P. Writing with Power. Techniques for Mastering the Writing Process. New York/Oxford: Oxford University Press; 1981.

7. Sloan DM, Marx BP. Taking pen to hand: Evaluating theories underlying the written disclosure. Clinical Psychol. 2004;11:121-137.

8. Gallagher S, D'Lima K, Tamba K, Elfick H, Head D, Bolton G. Healing writing in palliative care. In: Bolton $\mathrm{G}$, editor. Dying, Bereavement and the Healing Arts. London/Philadelphia: Jessica Kingsley Publishers; 2008:108-113.

9. Dysvik E, Furnes B. Dealing with grief related to loss by death and chronic pain: Suggestions for practice II. Patient Pref Adherence. 2010; 4:163-170.

10. Furnes B, Dysvik E. A systematic writing program as a tool in the grief process. Part 1. Patient Pref Adherence. In press.

11. Freud S. Mourning and melancholia. In: Strachey J, editor. The Standard Edition of the Complete Psychological Works of Sigmund Freud. London: Hogarth; 1917/1957.

12. Lindemann E. Symptomatology and management of acute grief. Am J Psychiatry. 1944;101:141-148.

13. Bowlby J. Attachment and Loss. New York: Books; 1980.

14. Parkes CM. Bereavement: Studies of Grief in Adult Life. London: Penguin; 1986.

15. Klass D, Silverman PR, Nickman SL. Continuing Bonds. New Understandings of Grief. New York: Taylor and Francis; 1996.

16. Neimeyer RA. Narrative strategies in grief therapy. Journal of Constructivist Psychology. 1999;12:65-85.

17. Wortmann C, Silver R. The myths of coping with loss revisited. In: Stroebe MS, Hansson RO, Stroebe W, Schut H, editors. Handbook of Bereavement Research. Washington DC: American Psychological Association; 2001:405-431.

Patient Preference and Adherence

\section{Publish your work in this journal}

Patient Preference and Adherence is an international, peer-reviewed, open access journal focusing on the growing importance of patient preference and adherence throughout the therapeutic continuum. Patient satisfaction, acceptability, quality of life, compliance, persistence and their role in developing new therapeutic modalities and compounds to
18. Attig T. Relearning the world: Making and finding meanings. In: Neimeyer RA, editor. Meaning, Reconstruction and the Experience of Loss. Washington DC: American Psychological Association; 2002: 33-53.

19. Neimeyer RA. Meaning, reconstruction and loss. In: Neimeyer RA, editor. Meaning, Reconstruction and the Experience of Loss. Washington, DC: American Psychological Association; 2002:1-9.

20. Shuchter SR, Zisook S. The course of normal grief. In: Stroebe MS, Stroebe W, Hansson RO, editors. Handbook of Bereavement, Theory, Research and Intervention. Cambridge: Cambridge University Press; 1993.

21. Furnes B, Dysvik E. Dealing with grief related to loss by death and chronic pain. An integrated theoretical framework I. Patient Pref Adherence. 2010;4:135-140.

22. Attig T. How We Grieve. Relearning the World. New York/Oxford: Oxford University Press; 1996.

23. Moules NJ, Simonson K, Prins M, Angus P, Bell JM. Making room for grief: Walking backwards and living forward. Nurs Inq. 2004;11: 99-107.

24. Furnes B. A skrive sorgen - bearbeidelse av sorg. Prosessorientert skriving i møte med en fenomenologisk språkforståelse. En hermeneutisk fenomenologisk studie av skriving som sorgbearbeidelse hos etterlatte. Doctoral thesis. University of Bergen, Norway; 2008.

25. Pahuus M. Holdning og spontanitet. Padagogik, menneskesyn og vardier. Århus: KvaN; 1997.

26. Ricoeur P. Time and Narrative, volume I. Chicago: The University of Chicago Press; 1984 (translated by Mc Laughlin K, Pellauer D, from: Temps et Récit I, Paris; 1983).

27. Ricoeur P. Time and Narrative, volume II. Chicago: The University of Chicago Press; 1985 (translated by Mc Laughlin K, Pellauer D, from: Temps et Récit II, Paris; 1984).

28. Ricoeur P. Time and Narrative, volume III. Chicago: The University of Chicago Press; 1988 (translated by Mc Laughlin K, Pellauer D, from: Temps et Récit III, Paris; 1985).

29. Parkes CM. Bereavement: Studies of Grief in Adult Life. London: Penguin; 1986.

30. Hoel TL. Å rydde veg for orda - eit gløtt inn i dei skjulte skriveprosessane. In: Lie S, Thowsen I, editors. Fagskriving som dialog. Oslo: Gyldendal Akademisk; 2000.

31. Britton J, Burgess T, Martin N, McLeod A, Rosen H. The Development of Writing Abilities. London: Macmillan Education; 1975:11-18.

32. Vygotsky L. Toenkning og Sprog II. København: H. Reizel; 1982.

33. MacKenzie KR. Time-Limited Group Psychotherapy. Washington DC: American Psychiatric Press; 1990.

34. Keefe FJ, Beaupre PM, Gil KM, Rumble ME, Aspnes AK. Group therapy for patients with chronic pain. In: Turk DC, Gatchel RJ, editors. Psychological Approaches to Pain Management. A Practitioner's Handbook. 2nd ed. New York: Guilford Press; 2002:234-255.

35. Pedersen B. Sygepleiepraksis. Sprog og Erkendelse. Doctoral thesis. Aarhus University, Denmark; 1999.

36. Pennebaker JW. Telling stories: The health benefits of narrative. Lit Med. 2000;19:3-11.

37. Smyth J, True N, Souto J. Effects of writing about traumatic experiences: The necessity for narrative structuring. J Soc Clin Psychol. 2001;20: $161-172$.

38. Pennebaker JW. Writing about emotional experiences as a therapeutic process. Psychol Med. 1997;8:162-166.

\section{Dovepress}

optimize clinical outcomes for existing disease states are major areas of interest. This journal has been accepted for indexing on PubMed Central. The manuscript management system is completely online and includes a very quick and fair peer-review system. Visit http://www.dovepress.com/ testimonials.php to read real quotes from published authors. 